\title{
Golgi Reassembly and Stacking Protein (GRASP) Participates in Vesicle-Mediated RNA Export in Cryptococcus neoformans
}

\author{
Roberta Peres da Silva ${ }^{1,2,+}$, Sharon de Toledo Martins ${ }^{3,+}{ }^{\dagger}$ Juliana Rizzo ${ }^{4}$, Flavia C. G. dos Reis ${ }^{3}$, \\ Luna S. Joffe ${ }^{5}$, Marilene Vainstein ${ }^{6}$, Livia Kmetzsch ${ }^{6}$, Débora L. Oliveira ${ }^{5}$, Rosana Puccia ${ }^{1}$, \\ Samuel Goldenberg ${ }^{3}$ (i), Marcio L. Rodrigues ${ }^{3,4}$ (i) and Lysangela R. Alves ${ }^{3, *}$ (i) \\ 1 Departamento de Microbiologia, Imunologia e Parasitologia da Escola Paulista de Medicina-UNIFESP, \\ São Paulo, SP 04023-062, Brazil; roberta.peresdasilva@nottingham.ac.uk (R.P.d.S.); \\ ropuccia@gmail.com (R.P.) \\ 2 School of Life Sciences, University of Nottingham, Nottingham NG7 2RD, UK \\ 3 Instituto Carlos Chagas, Fundação Oswaldo Cruz, Fiocruz-PR, Curitiba, PR 81310-020, Brazil; \\ sdt.martins@gmail.com (S.d.T.M.); flaviar23@gmail.com (F.C.G.d.R.); sgoldenb@fiocruz.br (S.G.); \\ marciolrodrig@gmail.com (M.L.R.) \\ 4 Instituto de Microbiologia Professor Paulo de Góes, Universidade Federal do Rio de Janeiro, Rio de Janeiro, \\ RJ 21941-901, Brazil; juju.rizzo@gmail.com \\ 5 Centro de Desenvolvimento Tecnológico em Saúde (CDTS), Fundação Oswaldo Cruz, Rio de Janeiro, \\ RJ 21040-900, Brazil; lujoffe@gmail.com (L.S.J.); debora_leite@yahoo.com.br (D.L.O.) \\ 6 Centro de Biotecnologia e Departamento de Biologia Molecular e Biotecnologia, \\ Universidade Federal do Rio Grande do Sul, Porto Alegre, RS 91501-970, Brazil; \\ mhv@cbiot.ufrgs.br (M.V.); liviak@cbiot.ufrgs.br (L.K.) \\ * Correspondence: lysangela.alves@fiocruz.br \\ + These authors contributed equally to this work.
}

Received: 1 July 2018; Accepted: 31 July 2018; Published: 8 August 2018

\begin{abstract}
Golgi reassembly and stacking protein (GRASP) is required for polysaccharide secretion and virulence in Cryptococcus neoformans. In fungal species, extracellular vesicles (EVs) participate in the export of polysaccharides, proteins and RNA. In the present work, we investigated if EV-mediated RNA export is functionally connected with GRASP in C. neoformans using a grasp $\Delta$ mutant. Since GRASP-mediated unconventional secretion involves autophagosome formation in yeast, we included the atg7 $\triangle$ mutant with defective autophagic mechanisms in our analysis. All fungal strains exported EVs but deletion of GRASP or ATG7 profoundly affected vesicular dimensions. The mRNA content of the grasp $\triangle$ EVs differed substantially from that of the other two strains. The transcripts associated to the endoplasmic reticulum were highly abundant transcripts in grasp $\triangle \mathrm{EVs}$. Among non-coding RNAs (ncRNAs), tRNA fragments were the most abundant in both mutant EVs but grasp $\Delta$ EVs alone concentrated 22 exclusive sequences. In general, our results showed that the EV RNA content from atg7 $\triangle$ and WT were more related than the RNA content of grasp $\Delta$, suggesting that GRASP, but not the autophagy regulator Atg7, is involved in the EV export of RNA. This is a previously unknown function for a key regulator of unconventional secretion in eukaryotic cells.
\end{abstract}

Keywords: Cryptococus neoformans; RNA; extracellular vesicles; GRASP; Atg7; unconventional secretory pathway 


\section{Introduction}

Extracellular vesicle (EV) formation and release constitute a ubiquitous export mechanism of proteins, DNA and RNA [1,2]. EVs play key roles in processes of cell communication, homeostasis, immunopathogenesis and microbial virulence [1,2]. EV formation is a conserved mechanism in both prokaryotic and eukaryotic cells [3]. In fungi, EVs participate in the transport of macromolecules across the cell wall [4-6]. Fungal EVs transport a variety of macromolecules including proteins, lipids, glycans, pigments and, as more recently described, RNA [4,6-9].

EV biogenesis in fungi is still poorly understood. It has been hypothesized that EV biogenesis in eukaryotes is a complex process that is regulated at multiple levels [10,11]. EV formation is part of the unconventional secretion machinery in eukaryotes and general regulators of unconventional secretion have been identified. GRASP (Golgi reassembly and stacking protein) is a secretion regulator originally characterized in human cells as part of the Golgi cisternae stacking and ribbon formation [12,13]. During stress, GRASP is required for protein delivery to the plasma membrane or to the extracellular space by an unconventional pathway that involves autophagosome-like structures [14]. In mammalian cells, GRASP is also involved in the delivery of a mutant form of cystic fibrosis transmembrane conductance regulator to the plasma membrane in a Golgi-independent manner [15]. In Drosophila melanogaster, GRASP participates in the delivery of integrins from the ER directly to the plasma membrane, thus bypassing the Golgi [16]. In the amoeba Dictyostelium discoideum, a GRASP orthologue (GrpA) was necessary for acyl-coenzyme A-binding protein (AcbA) secretion during spore differentiation [17]. In the yeast species Saccharomyces cerevisiae and Pichia pastoris, another GRASP orthologous (Ghr1) was also required for starvation-induced secretion of AcbA [18,19].

In the yeast-like neuropathogen Cryptococcus neoformans, GRASP was required for polysaccharide export to the extracellular space. Polysaccharide secretion is fundamental for virulence in C. neoformans [20] and, in fact, a grasp $\Delta$ mutant was hypovirulent in mice [20]. Polysaccharide export in C. neoformans is mediated by EVs but connections between GRASP functions and EV cargo remain uncharacterized.

Autophagy is a self-degradative process conserved in eukaryotes, presenting a housekeeping role by degrading dysfunctional components such as organelles and misfolded proteins [21]. The Atg7 is an autophagy regulator protein member of the ubiquitin-activating enzyme (E1) family involved in this process [22]. The Atg proteins have non-canonical roles in distinct cellular pathways. For example, Toxoplasma gondii Atg8 localizes to the apicoplast and is essential for organelle homeostasis and survival of the tachyzoite stage of the parasite [23]. Atg7 non-autophagic roles include cathepsin K secretion in bone osteoclasts [24], IFN $\gamma$-mediated antiviral activity against virus replication [25], adipogenesis in mice [26] and cell cycle regulation via p53 interaction and expression of p21 in mouse embryonic fibroblasts [27].

Autophagy regulators play key roles in cryptococcal physiology and, in fact, we have recently demonstrated that the putative autophagy regulator Atg7 affects both physiological and pathogenic mechanisms in C. neoformans [28]. In D. discoideum, GRASP-mediated unconventional secretion is mediated by autophagosomes, showing that there is a connection between these processes [18,29].

The role of unconventional secretion regulators in vesicular export of RNA is unknown but the functional connections between GRASP and Atg7 led us to evaluate whether these proteins affected extracellular RNA export in C. neoformans. Our results suggest that GRASP, but not Atg7, is a key regulator of vesicular export of RNA in C. neoformans.

\section{Material and Methods}

\subsection{Fungal Strains and Growth Conditions}

The C. neoformans strains used in this study included the parental isolate H99 and the mutant strains $\operatorname{atg} 7 \Delta$ and grasp $\Delta$, which were generated in previous studies by our group [20,28]. Fungal cultures were maintained at $30{ }^{\circ} \mathrm{C}$ in Sabouraud dextrose plates (1\% dextrose, $4 \%$ peptone). 
Cells recovered from the stationary cultures were used to inoculate minimal medium composed of dextrose $(15 \mathrm{mM}), \mathrm{MgSO}_{4}(10 \mathrm{mM}), \mathrm{KH}_{2} \mathrm{PO}_{4}(29.4 \mathrm{mM})$, glycine $(13 \mathrm{mM})$ and thiamine- $\mathrm{HCl}(3 \mu \mathrm{M})$ for further cultivation for three days at $30^{\circ} \mathrm{C}$, with shaking. All protocols adhered to the biosecurity demands of the Carlos Chagas Institute of Fiocruz (Curitiba, Brazil).

\subsection{Extracellular Vesicle Isolation and Diameter Determination}

EVs were isolated from fungal culture supernatants as previously described [4]. Briefly, cell-free culture supernatants were recovered by centrifugation at $4000 \times \mathrm{g}$ for $15 \mathrm{~min}$ at $4{ }^{\circ} \mathrm{C}$ and the resulting supernatants were pelleted at $15,000 \times g$ for $30 \mathrm{~min}$ to remove small debris. The final supernatants were concentrated by a factor of 20 in an Amicon ultrafiltration system (100-kDa cutoff, Millipore, Burlington, VT, USA). Concentrated supernatants were centrifuged at $15,000 \times g$ for $30 \mathrm{~min}$ to ensure the removal of aggregates and the resulting supernatant was then ultracentrifuged at $100,000 \times g$ for $1 \mathrm{~h}$ to precipitate vesicles. Vesicle pellets were washed once in phosphate-buffered saline (PBS) and the final pellets were suspended in PBS. For analysis of EV dimensions, nanoparticle tracking analysis (NTA) was performed on a LM10 Nanoparticle Analysis System, coupled with a $488 \mathrm{~nm}$ laser and equipped with a ${ }_{S} \mathrm{CMOS}$ camera and a syringe pump (Malvern Panalytical, Malvern, UK). The data was acquired and analyzed using the NTA 3.0 Software (Malvern Panalytical). EVs from all samples were diluted 1:30 in filtered PBS $(0.22 \mu \mathrm{M})$ and measured within the optimal dilution range previously described by Maas and colleagues $\left(9 \times 10^{7}-2.9 \times 10^{9}\right.$ particles $\left./ \mathrm{mL}\right)$ [30]. Polystyrene microspheres $(100 \mathrm{~nm})$ were used for equipment calibration. Samples were injected using a syringe pump speed of 50 and three videos of $60 \mathrm{~s}$ were captured per sample, with the camera level set to 15, gain set to 3 and viscosity set to water $(0.954-0.955 \mathrm{cP})$. For data analysis, the gain was set to 10 and detection threshold was set to 5 for all samples. Levels of blur and max jump distance were automatically set. Particle detection values were normalized to the total number of cells in cultures from which each sample was obtained.

\subsection{Small RNA Isolation}

Small RNA (sRNA)-enriched fractions were isolated with the miRNeasy mini kit (Qiagen, Hilden, Germany) and then treated with the RNeasy MinElute Cleanup Kit (Qiagen), according to the manufacturer's protocol, to obtain small RNA-enriched fractions. The success of the sRNA extraction was assessed in representative EV preparations that were treated with $30 \mathrm{U}$ DNase I (Qiagen) and characterized in an Agilent 2100 Bioanalyzer (Agilent Technologies, Santa Clara, CA, USA). To confirm that the RNA was confined within the EVs, vesicle samples were treated with $0.4 \mu \mathrm{g} \mu \mathrm{l}^{-1}$ RNase (Promega, Madison, WY, USA) for $10 \mathrm{~min}$ at $37^{\circ} \mathrm{C}$ before RNA extraction, as previously described [9].

\subsection{RNA Sequencing}

One hundred ng of purified sRNA were used for RNA-seq analysis from two independent biological replicates. The RNA-seq was performed in a SOLiD 3 plus platform using the RNA-Seq kit (Life Technologies, Carlsbad, CA, USA) according to the manufacturer's recommendations.

\subsection{Cellular RNA Isolation and Quantitative PCR}

Yeast cells were grown in minimal medium for $72 \mathrm{~h}$, pelleted by 1 min centrifugation at $14.000 \times g$, washed in PBS, suspended in the lysis buffer provided in miRCURYTM RNA Isolation Kit-Cell \& Plant (Exiqon, Vedbaek, Danmark) and vortexed 5 times in acid washed glass beads (425-600 micron, Sigma-Aldrich, St. Louis, MO, USA). The lysate was centrifuged for $2 \mathrm{~min}$ at $14.000 \times g$ and the supernatants were collected for RNA isolation with the mirCURY' ${ }^{\mathrm{TM}}$ kit, following the manufacturer's instructions. The RNAs were eluted in ultrapure water and treated with RQ1 RNase-Free Dnase (Promega) following the manufacturer's instructions. Reverse transcription reactions with the DNAse-treated RNAs were performed with a random primer and the ImProm-IIM Reverse Transcription System (Promega), following the manufacturer's instructions. Real time PCR 
reactions were performed using $\mathrm{SYBR}^{\circledR}$ Select Master Mix and run and analyzed using the LightCycler ${ }^{\circledR}$ 96 System (Roche, Basel, Switzerland). The primers corresponded to CNAG_03103 Cullin3 Forward GCCATACGGGAGATACAGAAC, Reverse GAGGTGTTGGACGATGAGAG, CNAG_07590 V_typeH Forward TCATGCTCAACGAAGTCAGG, Reverse GGAAGCAGTGGTTGTGAATG, CNAG_03337 hypothetic Forward CGGTCTTTATCGCTGCTGTAT, Reverse ATTGAAGAGTGGATGTCGTGG and CNAG_00483 Actin Forward CCACACTGTCCCCATTTACGA, Reverse CAGCAAGATCGATACGG AGGAT Each reaction was performed using $10 \mathrm{ng}$ of cDNA. The experiment was performed in triplicates and the expression levels relative to actin were calculated according to Pfaffl's method using $t$-test for the statistical analysis [31].

\subsection{In Silico Data Analysis}

The sequencing data were analyzed using the version 9.1 of CLC Genomics Workbench $\odot$. The reads were trimmed on the basis of quality, with a threshold Phred score of 15 . The reference genomes used for mapping were obtained from the NCBI database (C. neoformans-GCA_000149245.3). The alignment was performed as follows: additional 100-base upstream and downstream sequences; 10 minimum number of reads; 2 maximum number of mismatches; -2 nonspecific match limit and minimum fraction length of 0.9 for the genome mapping or 1.0 for the RNA mapping. The minimum reads similarity mapped on the reference genome was $80 \%$. Only uniquely mapped reads were considered in the analysis. The libraries were normalized per million and the expression values for the transcripts were recorded in RPKM (reads per kilobase per million), we also analyzed the other expression values-TPM (transcripts per million) and CPM (counts per million).

\subsection{Data Access}

The data is deposited to the Sequence Read Archive (SRA) database of NCBI (Bethesda, MA, USA) under study accession number (SRA: SRX2793565 to 67).

\section{Results}

\subsection{Lack of GRASP Results in Changes in the RNA Content of Cryptococcus neoformans Extracellular Vesicles}

Our experimental model included wild type (WT) and two mutant strains of $C$. neoformans. WT cells corresponded to strain H99, a standard and widely investigated clinical isolate. Knockout mutant strains (KO) lacked expression of two regulators of cryptococcal pathogenicity, GRASP and ATG7 [20,28].

We first asked whether the lack of either GRASP (grasp $\Delta$ ) or ATG7 (atg7D) expression would affect the EVs composition. The analysis of diameter distribution of wild type EVs by nanoparticle tracking analysis (Figure 1) revealed a major population of cryptococcal vesicles in the 50-250 nm range. Peaks of EVs corresponding to approximately 300, 410, 500 and $630 \mathrm{~nm}$ were also observed. Although the dimensions of cryptococcal EVs have been traditionally determined by dynamic light scattering and/or electron microscopy, the results obtained by nanoparticle tracking analysis were consistent with the previous literature [32]. Deletion of GRASP or ATG7 produced a clear impact on the size distribution of cryptococcal EVs. In comparison to WT cells, peaks corresponding to sizes higher than $300 \mathrm{~nm}$ were no longer observed. A minor peak at $225 \mathrm{~nm}$ and major, sharp peaks at 100 and $140 \mathrm{~nm}$ were observed in EVs produced by both mutants. Complementation of mutant cells resulted in EV fractions enriched in the 100-300 nm range, but the minor peaks at 415, 500 and $600 \mathrm{~nm}$ observed in WT cells were still not detectable. Although deletion of GRASP or ATG7 resulted in modified EV detection, no statistical differences were observed between the different samples. In summary, the nanoparticle tracking analysis revealed that deletion of GRASP and ATG7 affected EV properties in C. neoformans. We then asked whether the differences in EV diameters correlated with the RNA content in C. neoformans EVs. 

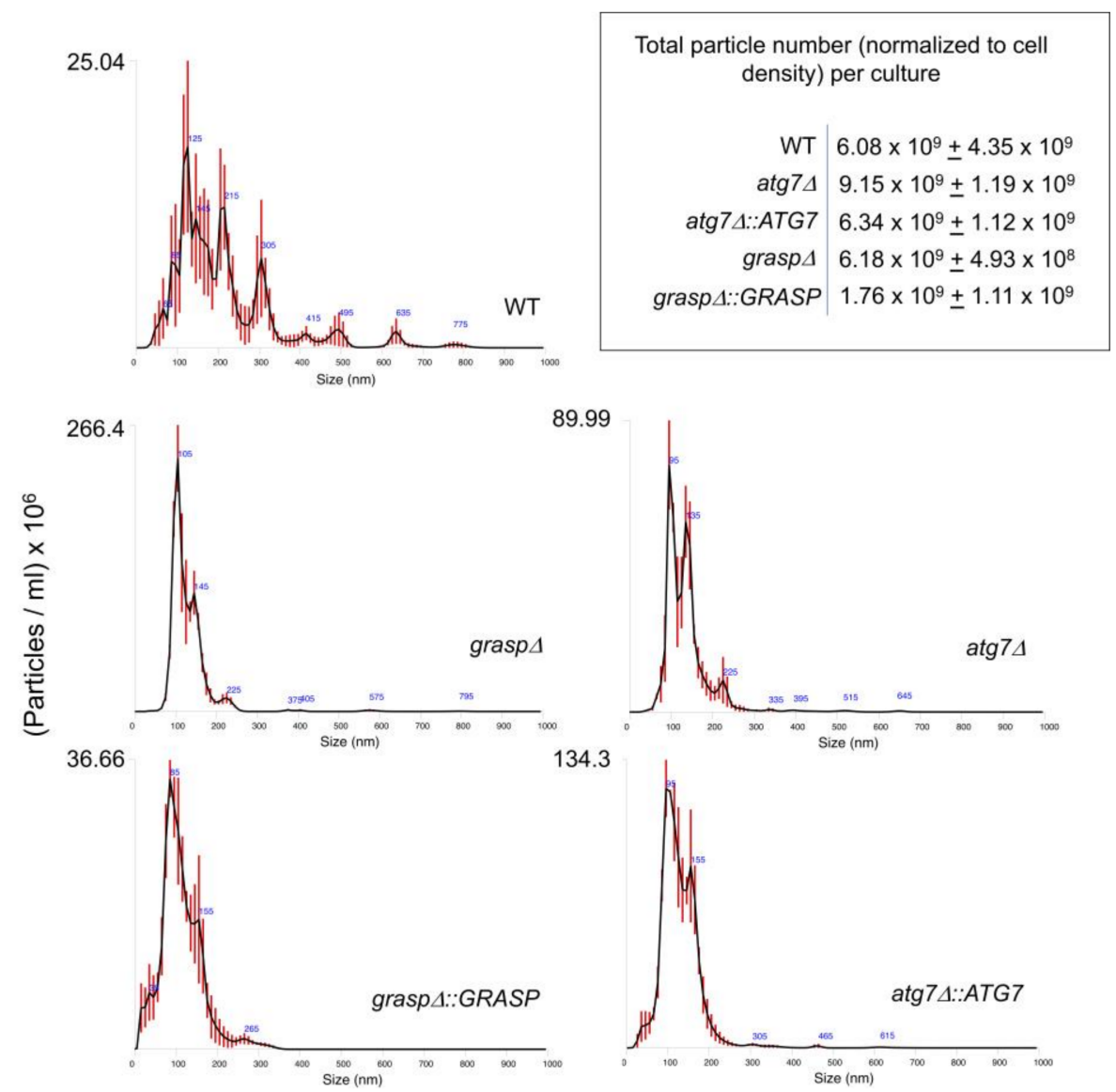

Figure 1. Nanoparticle tracking analysis of Cryptococcus neoformans extracellular vesicles (EVs) comparing wild type (WT), mutant (grasp $\Delta$ and $a t g 7 \Delta$ ) and complemented (grasp $\Delta:: G R A S P$ and atg7 $\triangle:: A T G 7)$ cells. Results are representative of two independent biological replicates producing similar profiles. Particles were quantified in EV samples suspended in $150 \mathrm{~mL}$ phosphate-buffered saline (PBS). Particle detection values shown in the upper, right panel were normalized to the total number of cells in the cultures from which each sample was obtained.

Total RNA was isolated from fungal EVs and two independent biological replicates were subjected to RNA-seq (Figure S1). In order to compare the EV-RNA composition between the knockout (atg7 $\Delta$ and grasp $\Delta$ ) and the WT strains we first aligned the RNA-seq reads with the C. neoformans $\mathrm{H} 99$ genome (GCA_000149245.3) sequences. We used the raw data available for isolate H99 from our previous work [9] and compared them with the atg7 $\Delta$ and grasp $\triangle$ EV RNA (Table 1). For all C. neoformans strains about $85 \%$ of the EV-RNA reads mapped to intronic regions, while less than $10 \%$ mapped to exons. A similar profile was observed for the C. neoformans WT strain (H99) in our previous work [9].

Analysis of EV-mRNAs showed that the correlation between WT and atg7 $(\mathrm{r} 0.71)$ sequences was greater than that for WT and grasp $\Delta$ (r 0.22) (Figure 2A,B). This result indicates that the mRNA content in WT EVs was closer to that of atg7 $\Delta$ vesicles than to the content of grasp $\Delta$ EVs. 
Table 1. RNA-seq mapping statistics. The values refer to the average of the replicates.

\begin{tabular}{ccccccc}
\hline & \multicolumn{4}{c}{ C. neoformans } \\
\cline { 2 - 7 } & \multicolumn{2}{c}{ WT } & \multicolumn{2}{c}{ atg7 } & \multicolumn{2}{c}{ grasp $\Delta$} \\
\cline { 2 - 7 } & $\begin{array}{c}\text { Uniquely } \\
\text { Mapped }\end{array}$ & $\begin{array}{c}\text { \% of Total } \\
\text { Mapped }\end{array}$ & $\begin{array}{c}\text { Uniquely } \\
\text { Mapped }\end{array}$ & $\begin{array}{c}\text { \% of Total } \\
\text { Mapped }\end{array}$ & $\begin{array}{c}\text { Uniquely } \\
\text { Mapped }\end{array}$ & $\begin{array}{c}\text { \% of Total } \\
\text { Mapped }\end{array}$ \\
\hline Exon & 5030 & 0.4 & 60,683 & 9.2 & 59,425 & 7.5 \\
Exon-exon & 10,664 & 0.6 & 1458 & 0.2 & 2350 & 0.3 \\
Total exon & 113,655 & 9.7 & 62,141 & 9.4 & 61,774 & 7.8 \\
Total intron & $1,003,971$ & 90.3 & 568,003 & 84.9 & 758,109 & 86.9 \\
Total gene & $1,117,625$ & 100 & 667,288 & 100.0 & 861,092 & 100.0 \\
\hline
\end{tabular}
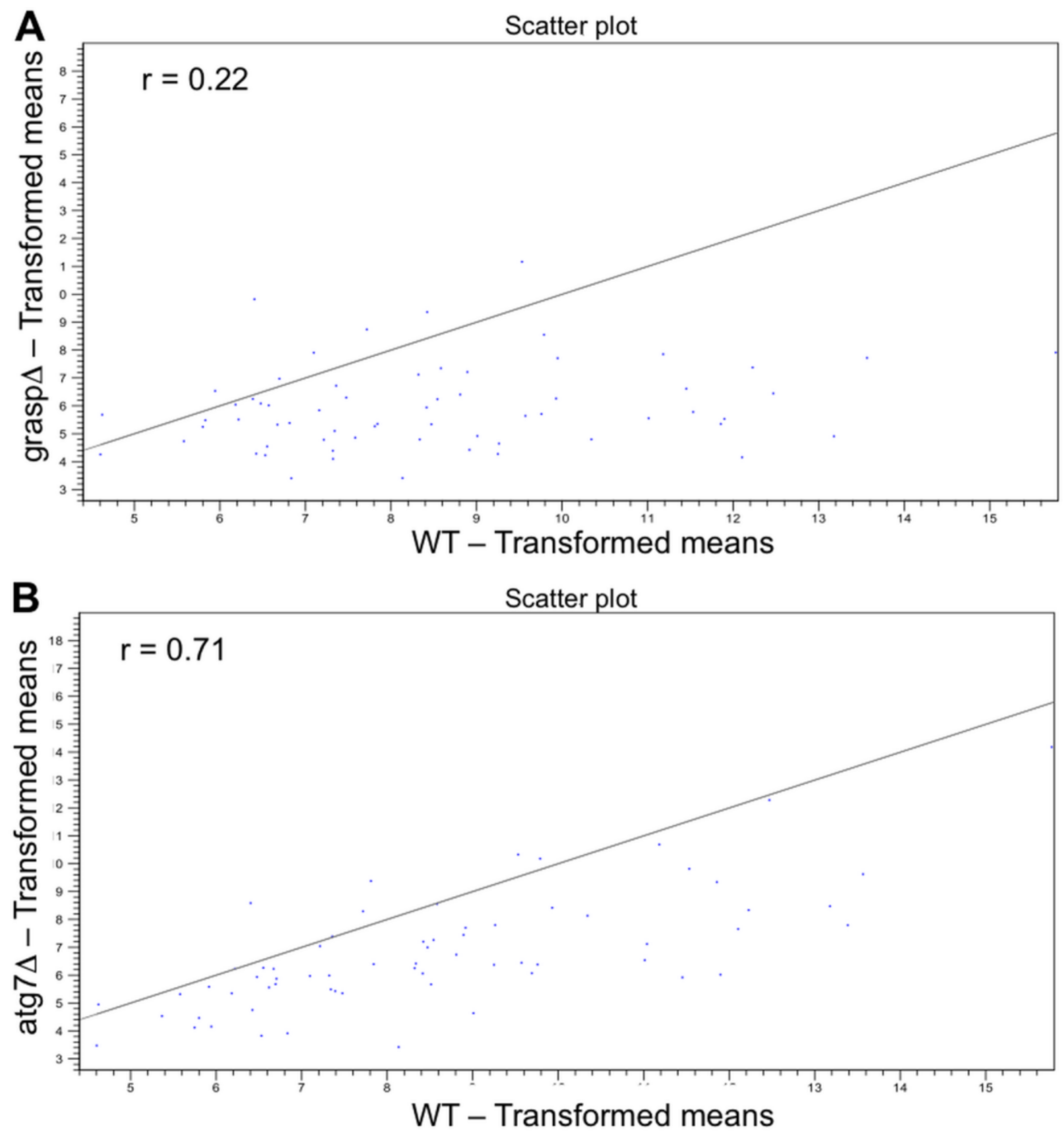

Figure 2. Correlation between the EV-mRNA sequences of grasp $\Delta$ vs. WT samples (A) and $\operatorname{atg} 7 \Delta$ vs. WT preparations (B). The transformed mean read values for WT EVs are in the X-axis, while those obtained from mutant vesicles are in the $y$-axis.

We next performed paired comparisons (WT versus grasp $\Delta$ and WT versus atg7 $\Delta$ ) and applied the statistical negative binomial test [33] and the filters RPKM $\geq 50, \log 2 \geq 2$ and false discovery rate (FDR) $\leq 0.01$. From the WT versus grasp $\Delta$ analysis, $266 \mathrm{mRNAs}$ were identified as enriched in the EVs from the grasp $\Delta$ mutant (Table S1). From these transcripts, we observed enrichment in cellular components $(p \leq 0.03)$ such as membrane and endoplasmic reticulum (Figure 3). For biological processes $(p \leq 0.03)$, 
the enriched terms included organelle organization, cell cycle and gene expression (Figure 3). For the WT versus atg $7 \Delta$ analysis, 74 mRNAs were found enriched in the atg $7 \Delta$ compared to the WT strain (Table S2). The most abundant cellular components mRNAs $(n=75)$ in $\operatorname{atg} 7 \Delta$ EVs were the nucleus and the mitochondrion (Figure 4). Biological processes were associated to transcription, transcription regulation and RNA processing (Figure 4). However, the score values for some terms did not meet the statistics criteria $(p \leq 0.03)$.

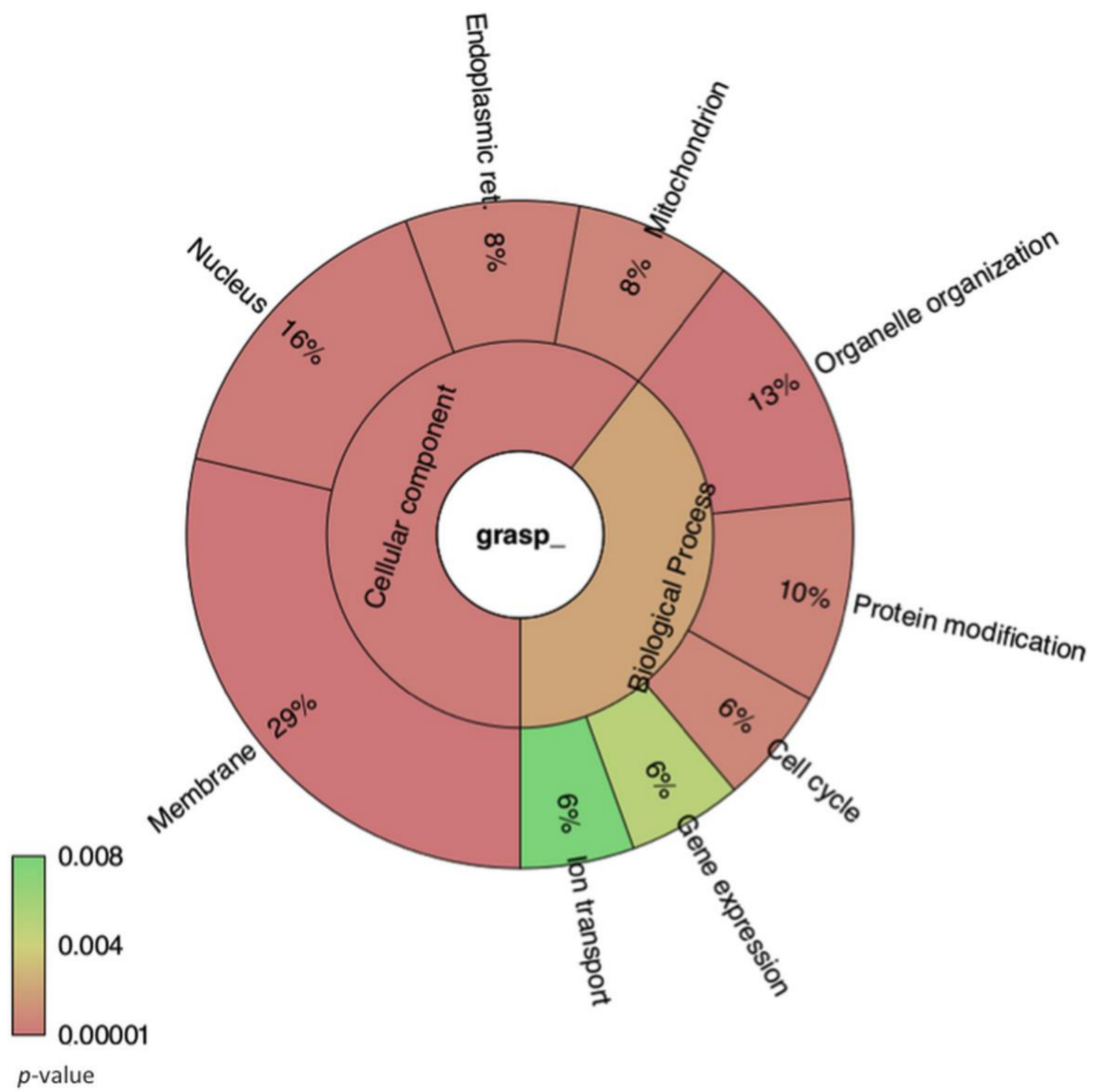

Figure 3. Krona chart representing the gene ontology of mRNA sequences enriched in EVs isolated from the C. neoformans grasp $\Delta$ mutant. The percentage refers to the relative enrichment for the Gene Ontology (GO) terms. The colors represent the $p$-value for each term plotted in the chart. 


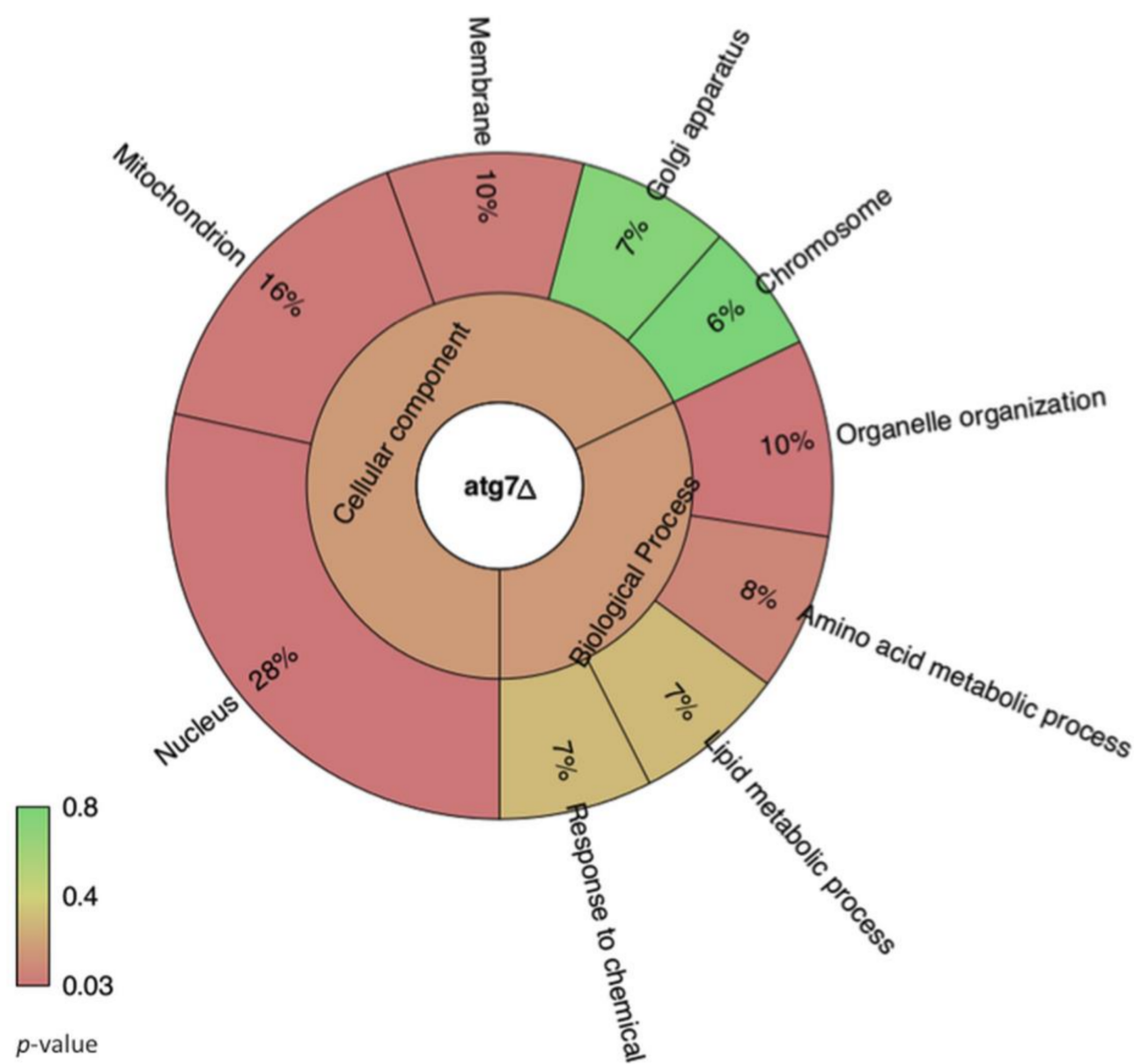

Figure 4. Krona chart representing the gene ontology of mRNA sequences enriched in EVs isolated from the $C$. neoformans atg $7 \Delta$ mutant. The percentage refers to the relative enrichment for the GO terms. The colors represent the $p$-value for each term plotted in the chart.

Noteworthy, the second and third most abundant transcripts exclusively identified in grasp $\Delta$ EVs were those for the ER lumen protein retaining receptor and the regulator of vesicle transport through interaction with t-SNAREs 1 (Table S1). The former determines specificity of the luminal ER protein retention system and is required for normal vesicular traffic through the Golgi. The latter is involved in multiple transport pathways [34,35]. In addition, most of the transcripts were associated to organelles, such as the nucleus, the mitochondrion and the endoplasmic reticulum, suggesting that somehow the GRASP knockout resulted in altered population of transcripts composing the EVs. This enrichment profile was not observed in the ATG7 knockout (Table S2), thus validating the differences observed in the grasp $\Delta$ mutant EVs.

As we observed this alteration in the EV-RNA composition for the grasp $\triangle$ mutant we asked if this difference was due to a general alteration in the cell transcriptome caused by the GRASP knockout. We then selected three of the most enriched transcripts found in the grasp $\triangle$ mutant EVs and assessed their expression value by qPCR in WT, mutant (grasp $\Delta$ and $\operatorname{atg} 7 \Delta$ ) and complemented (grasp $\triangle:: G R A S P$ and $\operatorname{atg} 7 \triangle:: A T G 7$ ) strains (Figure 5). The expression values of cullin 3, hypothetical protein CNAG_03337 and the V-type $\mathrm{H}$ transporting ATPase subunit $\mathrm{C}$ transcripts were similar in WT and grasp $\Delta$ mutant strains, despite the mRNA alteration in the EVs obtained from these two strains. The atg7 $\Delta$ mutant showed the highest expression levels of these mRNAs when compared to the WT and grasp $\Delta$ strains (Figure 5). In addition, these transcripts had very low identification or were not detected in EVs from the atg7 $7 \Delta$ strain (Table S2). Therefore, despite of the fact that atg $7 \Delta$ mutant showed high expression levels, this variation did not correlate with the presence of these transcripts in EV fractions. Analysis of the complemented strains demonstrated a partial restoration of the wild-type 
phenotype in the atg7 $\triangle$ system (Figure 5). Altogether, these results reinforce the notion that the GRASP deletion lead to a shift in the RNA composition of cryptococcal EVs.
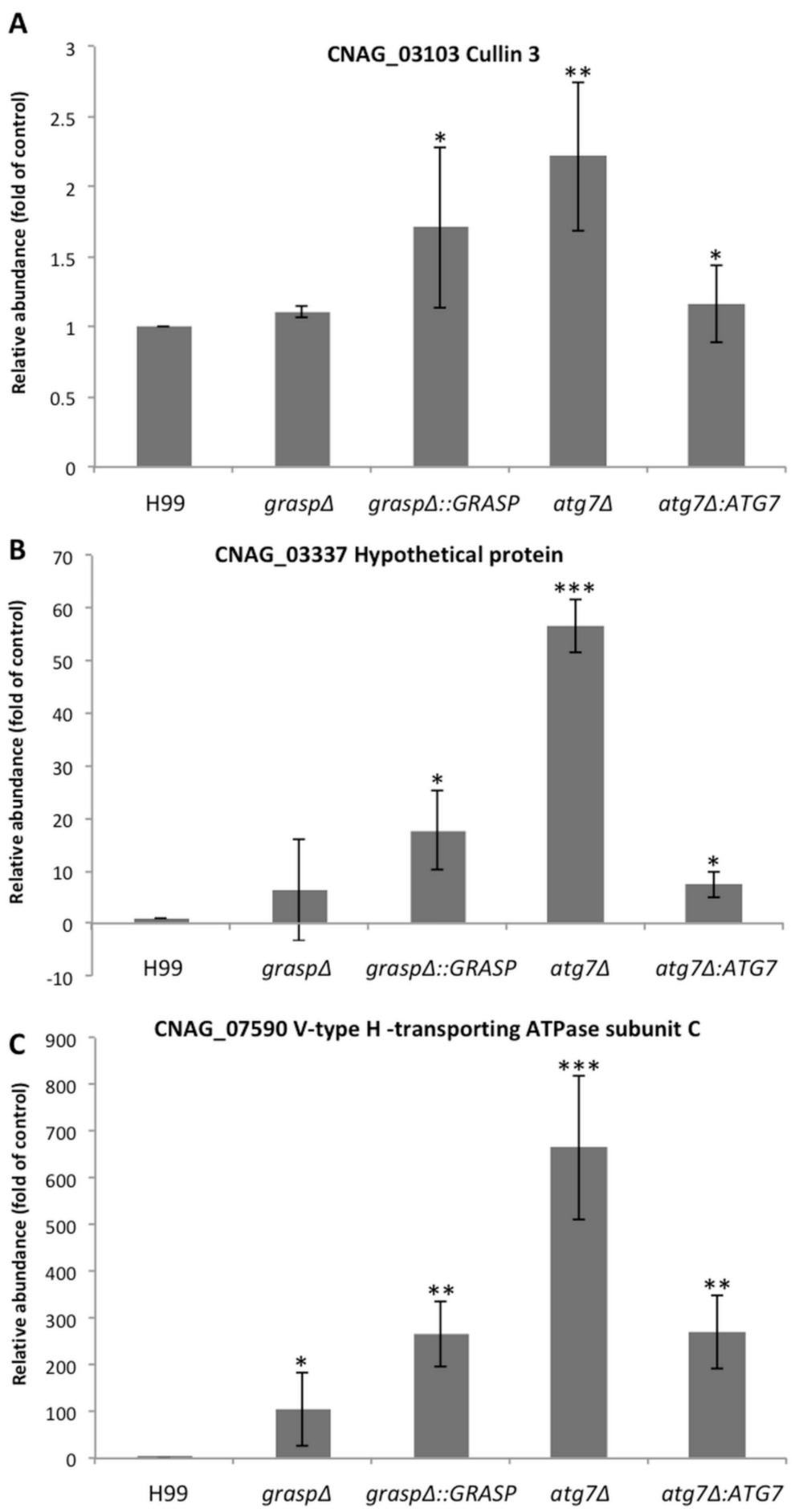

Figure 5. Analysis of the cellular transcription levels of three vesicular RNA sequences. Transcript levels for (A) Cullin 3; (B) hypothetical protein CNAG_03337 and (C) V-type $\mathrm{H}^{+}$-transporting ATPase subunit $\mathrm{C}$ were normalized to the levels of actin transcripts. The $\mathrm{X}$-axis corresponds to each strain analyzed (WT, grasp $\Delta$, grasp $\Delta:: G R A S P$, atg7 $\Delta$ and $\operatorname{atg} 7 \Delta:: A T G 7)$. The $y$-axis corresponds to the relative expression level of the mRNAs in the cell. Each bar represents the mean and standard error of triplicate samples. ${ }^{*} p<0.05 ;{ }^{* *} p<0.01 ;{ }^{* * *} p<0.001$. 


\subsection{Comparison of Cellular RNA Versus Extracellular Vesicle RNA Composition}

The differences in the RNA composition of EVs produced by the grasp $\Delta$ strain led us to question whether the mRNAs in the EVs correspond to those highly expressed in the cell, likely resulting from random incorporation into vesicular carriers [36]. To address this hypothesis, we compared the C. neoformans transcriptome (H99 strain) with the vesicular RNA sequences [9,37] (Table S3). After applying the differential gene expression analysis (DGE) we observed that, for several transcripts, there was an inversion between the expression patterns in the cell and the RNA abundance in the EVs (Figure 6 and Table 2). For example, one of the most enriched transcripts in the EVs presented low levels of expression in the cell (CNAG_06651 amidohydrolase). On the other hand, CNAG_03012 (encoding a quorum sensing-like molecule) had an RPKM value greater than 20,000 in the cell but showed low abundance in the EVs (average RPKM value of 36; Table 3 and Table S3). This observation indicates a lack of correlation between the most expressed cellular mRNAs and EV cargo, therefore reinforcing the supposition that RNA loading into WT or mutant EVs is not random.

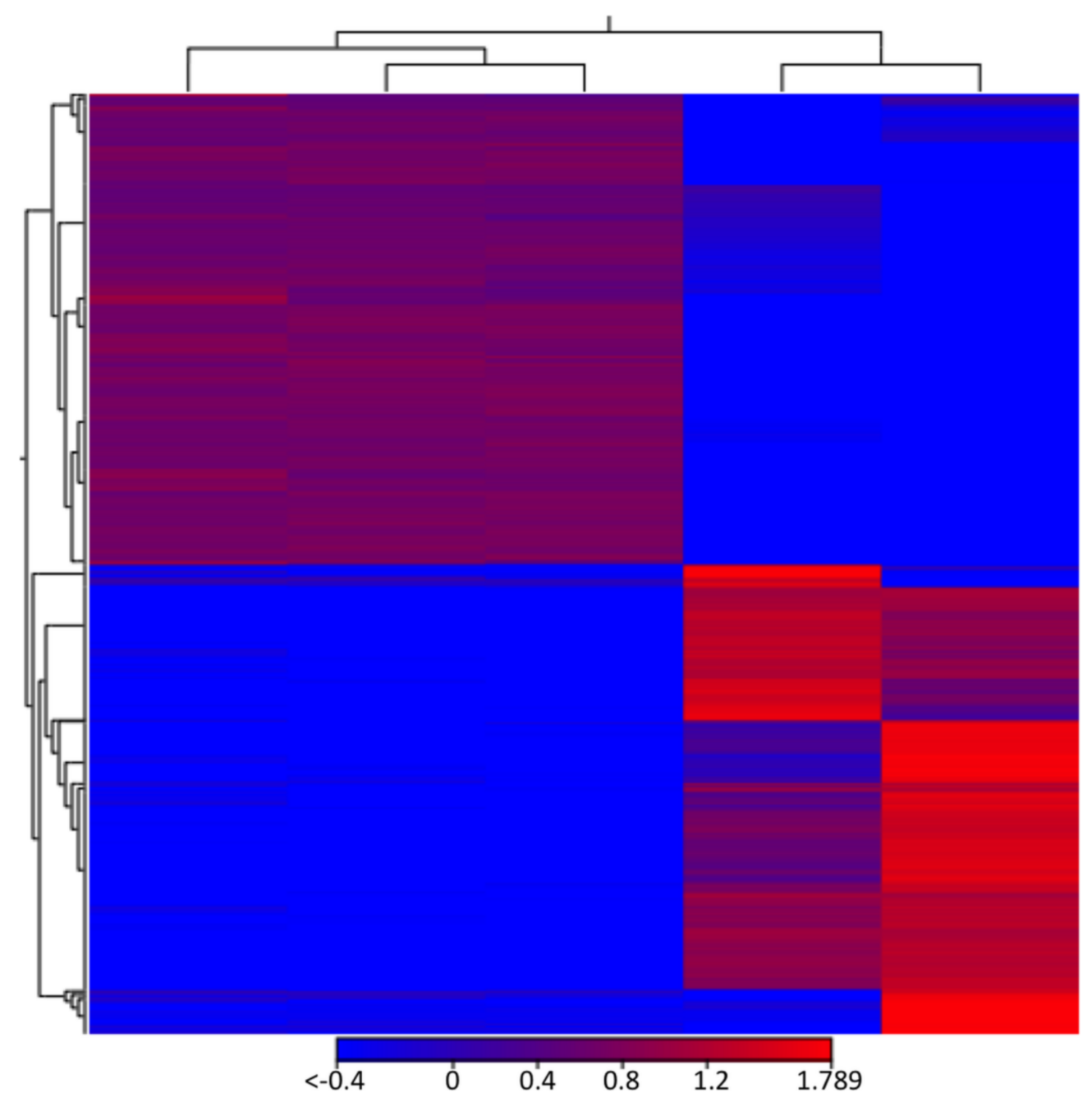

Figure 6. Heat map illustration of the comparison between cellular and EV RNAs. The expression levels are visualized using a gradient color scheme, where the red color is used for high expression levels and the blue color is used for low expression levels. Each line corresponds to a gene of the $C$. neoformans H99 strain. 
Table 2. Comparison between cellular and vesicular RNA in C. neoformans (H99 strain). The top ten most expressed transcripts in the cell are shown in light blue. The most represented RNAs in the EVs are illustrated in light red.

\begin{tabular}{|c|c|c|c|c|c|c|c|c|}
\hline Name & Product & $\begin{array}{l}\text { EV vs. Cell-Log } \\
\text { Fold Change }\end{array}$ & $\begin{array}{l}\text { EV vs. } \\
\text { Cell-FDR } \\
p \text {-Value }\end{array}$ & $\begin{array}{l}\text { SRR3199612 } \\
\text { Cell } 1 \text { RPKM }\end{array}$ & $\begin{array}{l}\text { SRR3199613 } \\
\text { Cell 2-RPKM }\end{array}$ & $\begin{array}{l}\text { SRR3199614Cell } \\
\text { 3-RPKM }\end{array}$ & $\begin{array}{l}\text { EV RNA } \\
\text { 1-RPKM }\end{array}$ & $\begin{array}{l}\text { EV RNA } \\
\text { 2-RPKM }\end{array}$ \\
\hline CNAG_03012 & quorum sensing-like molecule & -5.06 & $0.00 \%$ & $20,332.13$ & $18,844.93$ & $20,155.19$ & 48.40 & 24.28 \\
\hline CNAG_06207 & hypothetical protein & -6.93 & $0.00 \%$ & $16,304.37$ & $14,037.19$ & $13,815.62$ & 8.35 & 6.02 \\
\hline CNAG_04105 & hypothetical protein & -2.31 & $2.29 \%$ & $16,003.01$ & $10,010.74$ & $16,467.89$ & 254.98 & 73.62 \\
\hline CNAG_03143 & hypothetical protein & -2.09 & $3.87 \%$ & $13,070.91$ & 8338.53 & $12,401.56$ & 231.90 & 78.39 \\
\hline CNAG_01735 & hypothetical protein & -3.60 & $0.03 \%$ & 9034.37 & 6373.02 & 7970.58 & 56.97 & 16.11 \\
\hline CNAG_06075 & hypothetical protein & -2.98 & $0.39 \%$ & 6021.45 & 5119.83 & 6051.19 & 66.75 & 13.02 \\
\hline CNAG_03007 & hypothetical protein & -6.58 & $0.00 \%$ & 5861.25 & 5356.39 & 4321.23 & 3.72 & 2.64 \\
\hline CNAG_06298 & hypothetical protein & -7.02 & $0.00 \%$ & 5319.83 & 5499.72 & 6635.36 & 2.65 & 3.96 \\
\hline CNAG_06101 & ADP, ATP carrier protein & -3.04 & $0.11 \%$ & 4475.82 & 5415.80 & 4535.39 & 44.21 & 32.06 \\
\hline CNAG_07466 & $\begin{array}{c}\text { U3 small nucleolar } \\
\text { RNA-associated protein 7, U3 } \\
\text { small nucleolar } \\
\text { RNA-associated protein 7, } \\
\text { variant 1, U3 small nucleolar } \\
\text { RNA-associated protein 7, } \\
\text { variant 2 }\end{array}$ & 10.05 & $0.00 \%$ & 392.25 & 765.29 & 487.61 & $39,204.58$ & $43,212.28$ \\
\hline CNAG_01093 & hypothetical protein & 8.04 & $0.00 \%$ & 45.01 & 41.14 & 33.25 & 831.32 & 480.72 \\
\hline CNAG_06651 & amidohydrolase & 12.70 & $0.00 \%$ & 3.80 & 4.64 & 3.38 & 777.33 & 4354.12 \\
\hline CNAG_00311 & $\begin{array}{l}\text { 3-hydroxyisobutyryl-CoA } \\
\text { hydrolase }\end{array}$ & 6.97 & $0.00 \%$ & 62.61 & 78.16 & 54.48 & 650.07 & 373.07 \\
\hline CNAG_02129 & hypothetical protein & 2.12 & $3.76 \%$ & 423.90 & 380.09 & 587.72 & 178.91 & 56.55 \\
\hline CNAG_05774 & $\begin{array}{c}\text { hypothetical protein, } \\
\text { hypothetical protein, variant }\end{array}$ & 4.48 & $0.00 \%$ & 87.07 & 87.32 & 82.46 & 146.53 & 104.07 \\
\hline CNAG_05651 & hypothetical protein & 7.83 & $0.00 \%$ & 5.28 & 8.41 & 7.53 & 138.73 & 51.57 \\
\hline CNAG_07515 & hypothetical protein & 4.79 & $0.00 \%$ & 57.55 & 52.26 & 77.35 & 118.53 & 127.65 \\
\hline CNAG_04124 & hypothetical protein & 7.66 & $0.00 \%$ & 6.60 & 6.26 & 5.59 & 113.90 & 21.83 \\
\hline CNAG_07028 & $\begin{array}{l}26 \mathrm{~S} \text { proteasome regulatory } \\
\text { subunit N11 }\end{array}$ & 4.03 & $0.00 \%$ & 103.45 & 112.54 & 86.34 & 112.59 & 118.66 \\
\hline
\end{tabular}


Table 3. Intron retention in EV RNAs.

\begin{tabular}{|c|c|c|c|c|c|c|c|c|c|c|c|c|c|c|}
\hline \multirow[t]{2}{*}{ ID } & \multicolumn{4}{|c|}{$\begin{array}{l}\text { Data obtained from } \\
\text { Gonzalez-Hilarion et al., } 2016 \text { [38] }\end{array}$} & \multirow[t]{2}{*}{ RPKM } & \multirow{2}{*}{$\begin{array}{c}\begin{array}{c}\text { Unique } \\
\text { Exon } \\
\text { Reads }\end{array} \\
\text { WT } \\
\end{array}$} & \multirow[t]{2}{*}{$\begin{array}{c}\text { Unique } \\
\text { Intron } \\
\text { Reads }\end{array}$} & \multirow[t]{2}{*}{ RPKM } & \multirow{2}{*}{ 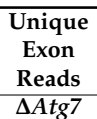 } & \multirow[t]{2}{*}{$\begin{array}{l}\text { Unique } \\
\text { Intron } \\
\text { Reads }\end{array}$} & \multirow[t]{2}{*}{ RPKM } & \multirow{2}{*}{ 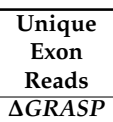 } & \multirow[t]{2}{*}{$\begin{array}{l}\text { Unique } \\
\text { Intron } \\
\text { Reads }\end{array}$} & \multirow[t]{2}{*}{ Product } \\
\hline & intron & Type & RPKM & Exons & & & & & & & & & & \\
\hline CNAG_03602 & $\begin{array}{l}\text { Ic2-554 } \\
\text { Ic2-555 }\end{array}$ & $\begin{array}{l}\text { in5UTR } \\
\text { in5UTR }\end{array}$ & $\begin{array}{c}6.66 \\
204.80\end{array}$ & 5 & 23.5 & 4 & 228 & 40.59 & 3 & 87.5 & 28.57 & 1.5 & 81 & U3 small nucleolar RNA-associated protein 5 \\
\hline CNAG_03645 & $\begin{array}{l}\text { Ic2-787 } \\
\text { Ic2-788 }\end{array}$ & $\begin{array}{l}\text { inCDS } \\
\text { inCDS }\end{array}$ & $\begin{array}{c}8.01 \\
12.93\end{array}$ & 8 & 6.3 & 1.5 & 73.5 & 53.43 & 5.5 & 9.5 & 58.98 & 6.5 & 14.5 & $\begin{array}{l}\text { NET1-associated nuclear protein } 1 \text { (U3 small } \\
\text { nucleolar RNA-associated protein 17) }\end{array}$ \\
\hline CNAG_04068 & Ic2-3155 & inCDS & 3.18 & 4 & 71.2 & 3.5 & 10 & 270.93 & 6 & 11 & 522.07 & 12 & 4.5 & large subunit ribosomal protein L28e \\
\hline CNAG_07982 & $\begin{array}{l}\text { Ic4-247 } \\
\text { Ic4-248 }\end{array}$ & $\begin{array}{l}\text { inCDS } \\
\text { inCDS }\end{array}$ & $\begin{array}{c}6.96 \\
17.47\end{array}$ & 5 & 1061.8 & 60.5 & 100.5 & 81.42 & 5 & 3 & 60.25 & 3.5 & 7 & hypothetical protein \\
\hline CNAG_00930 & $\begin{array}{l}\text { Ic4-351 } \\
\text { Ic4-349 } \\
\text { Ic4-350 }\end{array}$ & $\begin{array}{l}\text { inCDS } \\
\text { in5UTR } \\
\text { in5UTR }\end{array}$ & $\begin{array}{c}2.61 \\
1066.15 \\
81.59\end{array}$ & 7 & 50.1 & 5.5 & 328 & 81.47 & 4 & 303.5 & 106.30 & 6 & 397 & argininosuccinate synthase \\
\hline CNAG_07884 & Ic8-1359 & inCDS & 10.84 & 3 & 7.4 & 0.5 & 66 & 18.73 & 0.5 & 21.5 & 85.27 & 2.5 & 21 & hypothetical protein \\
\hline CNAG_07813 & $\begin{array}{l}\text { Ic12-778 } \\
\text { Ic12-776 }\end{array}$ & $\begin{array}{l}\text { inCDS } \\
\text { in5UTR }\end{array}$ & $\begin{array}{l}8.46 \\
7.38\end{array}$ & 5 & 75.4 & 6.5 & 231.5 & 14.71 & 0.5 & 141.5 & 37.66 & 1 & 208.5 & hypothetical protein \\
\hline CNAG_06167 & Ic13-990 & in5UTR & 26.36 & 5 & 131.1 & 11 & 770 & 103.14 & 6.5 & 152.5 & 146.05 & 10.5 & 295 & metal homeostatis protein bsd2 \\
\hline CNAG_01820 & Ic3-1947 & in3UTR & 28.14 & 12 & 342.4 & 47 & 180.5 & 236.94 & 17 & 15.5 & 344.85 & 27.5 & 15 & pyruvate kinase, pyruvate kinase, variant \\
\hline CNAG_06033 & Ic13-230 & inCDS & 10.93 & 7 & 99.4 & 15 & 22 & 47.14 & 3.5 & 5 & 33.92 & 3.5 & 63.5 & pfkB family carbohydrate kinase superfamily \\
\hline CNAG_03730 & Ic2-1335 & in5UTR & 35.87 & 4 & 41.7 & 2 & 479.5 & 102.24 & 2 & 23.5 & 0.00 & 0 & 175.5 & $\begin{array}{l}\text { DNA-directed RNA polymerase II subunit } \\
\text { RPB11 }\end{array}$ \\
\hline CNAG_06401 & Ic14-772 & in5UTR & 14.61 & 11 & 6.1 & 0.5 & 23 & 52.25 & 4.5 & 162.5 & 28.12 & 2.5 & 27.5 & hypothetical protein \\
\hline
\end{tabular}




\subsection{Intronic Reads}

We have previously observed that a great number of $C$. neoformans EV-RNA reads mapped to intronic regions of the genome [9], which is in agreement with our current findings with the knockout strains. To analyze intronic reads in mRNAs and exclude non-coding RNAs (ncRNAs), such as ribosomal RNA (rRNA) or transfer RNA (tRNAs), we used the presence of exons as a criterion to ensure ncRNAs were excluded (Table 3). We observed two types of patterns, including reads mapping to both exons and introns in variable proportions and those that mapped only to introns in the messenger RNAs. The intronic mapping shared by the EV RNAs from the WT and mutant strains of $C$. neoformans were associated to translation and also to transmembrane proteins (Table 3). From the 32 mRNAs with intronic reads found in the EV samples, 12 have previously been described as transcripts with intron retention [38]. It has already been reported that $59 \%$ of the genes from C. neoformans use alternative splicing (AS) that varies depending on the growth conditions. The intron retention (IR) is the prevalent AS mechanism in this fungus [38]. We also observed differences in abundance between the cell mRNAs compared to those in the EVs (Table 3). For example, the mRNA CNAG_07982 that codes for a hypothetical protein is 10 times more abundant in the EV than in the cell. A similar profile was observed for sequence CNAG_01820, which encodes a pyruvate kinase (Table 3). It has been speculated that the mRNAs that present IR are not the most expressed in cells based on a negative correlation between the highly expressed transcripts and the presence of IR [38]. However, our present data show that most of the reads that were considered as aligned in introns, are in fact the rRNAs 25S, $18 \mathrm{~S}$ and $5.8 \mathrm{~S}$ (data not shown). Nevertheless, we obtained highly abundant transcripts that are likely to be intron-retaining mRNAs (Table 3), suggesting that somehow these IR mRNAs might be directed to the EVs. The function of these transcripts needs to be further investigated.

\subsection{Non-Coding RNAs}

The EV-RNA sequences obtained in this work also mapped to ncRNAs. The most abundant molecules were the 25S, $18 \mathrm{~S}$ and $5.8 \mathrm{~S}$ rRNAs, accounting for more than $90 \%$ of the ncRNA and intronic reads (data not shown). As described for the mRNA analysis, we performed paired comparisons (WT versus grasp $\Delta$ and WT vs. atg7 $\Delta$ ) and applied the statistical negative binomial test [33] and the filters $R P K M \geq 50, \log 2 \geq 2$ and FDR $\leq 0.01$. For the WT versus grasp $\Delta$ we observed 43 ncRNAs enriched in grasp $\Delta$ (Table S4). For WT versus atg7 30 ncRNAs were enriched in the atg7 $\Delta$ strain (Table S5). From these results, it was possible to observe that the tRNA-derived fragments (tRFs) were enriched in both knockouts (Table S4 and S5). tRFs have been identified in EVs from organisms in all kingdoms, including archaea, bacteria and eukaryotes, where they play different biological roles [39].

\section{Discussion}

Fungal extracellular vesicles might correspond to structures that randomly incorporate cytosolic molecules that are released extracellularly or in the cell wall [11]. Our current results, however, suggest that EV RNA cargo can be finely regulated. Our model consisted of an investigation of the role of C. neoformans proteins GRASP and Atg

7 in the vesicular export of RNA. Although these proteins are functionally connected in other systems [12,17,26,27], our findings suggest that GRASP, but not Atg7, has a fundamental role in addressing RNA to cryptococcal EVs. The Atg proteins, which are primarily linked to autophagy processes, have non-canonical roles in distinct cellular pathways. It seems clear, however, that despite the variety of functions played by Atg7 and the significant alterations that its gene deletion causes in C. neoformans, the RNA populations transported by EVs were not greatly affected by the atg7 knockout in C. neoformans. The phenotypic characteristics of this mutant included more efficient melanization, larger cell size, autophagic bodies formation and virulence attenuation [28].

Remarkably, phenotypic traits including EV dimensions were only partially recovered in complemented strains. This observation is likely related to methodological particularities intrinsic to 
the genetic manipulation of C. neoformans. For instance, biolistic transformation usually results in large chromosomic alterations but most importantly, gene complementation results in random insertion of ATG7- or GRASP-containing cassettes in multiple chromosome loci. Under these conditions, many phenotypic traits can be unpredictably affected and complemented genes can have their expression altered. In the specific case of GRASP, complementation of the graspD strain used in this study resulted in GRASP overexpression [20,28], which might be related to the unique phenotypic properties of the complemented strain.

Sequencing analysis of vesicular RNA obtained from mutant strains suggested that important biological functions are associated with nucleic acid-containing fungal vesicles. For example, the tRF-3'end derived (or CCA) uses the canonical miRNA machinery to downregulate replication of protein A1 mRNA and other transcripts in B cell lymphoma [40]. Regulation of translation is also a potential process where tRFs participate. It was demonstrated that $t R F$ derived from $t R N A-V a l$ in the archaebacteria Haloferax volcanii binds to the small ribosomal subunit, consequently repressing translation by preventing a peptidyl transferase activity [41]. tRFs are also associated to the regulation of cell viability, RNA turnover and RNA stability [42-45]. The roles of GRASP and Atg7 in these processes have not been established but the enrichment of specific classes of RNA in mutant EVs suggests the existence of robust connections between EV traffic and tRFs. In Trypanosoma cruzi, the causing agent of Chagas disease, tRF-containing EVs can be transferred to other parasites and/or to host cells to modulate gene expression or facilitate infection [46,47]. In EVs from dendritic and $\mathrm{T}$ cells there are different populations of tRFs indicating selective loading of these molecules into the vesicles [48]. Human semen EVs are enriched with tRFs that hypothetically act as translational repressors [49]. It is unknown whether fungal vesicles can be transferred to other cells and consequently regulate metabolism and gene expression but it is tempting to speculate this hypothesis based on the findings mentioned above.

The mRNA population from grasp $\Delta$ EVs had low correlation with WT vesicles. In addition, ncRNA populations were also clearly distinct in EVs from WT and grasp $\Delta$ cells, where snoRNA predominated in the WT and tRNA/tRFs in the KOs.

The distinct RNA cargo in the mutants analyzed in this study is in agreement with a key and general role of GRASP in unconventional secretion in C. neoformans and a minor participation of Atg7. Polysaccharides, which lack secretory tags, require GRASP for efficient secretion in C. neoformans [20]. Deletion of ATG7, however, did not affect polysaccharide export in this fungus [28]. Multivesicular body formation and consequent exosome release involve a number of cellular regulators whose functions directly affect EVs [50,51]. In fungi, a number of regulators affect biogenesis of exosome-like EVs, including the ESCRT machinery, flippases and GRASP [52]. It has been hypothesized that GRASP (Grh1) could participate in this process by acting as a chaperone and directly influencing the cargo of EVs [53]. This GRASP chaperone function could be linked to our current results since RNA cargo was deeply affected in the grasp $\Delta$ mutant. Altogether, these results strongly indicate a novel function for the GRASP family in eukaryotes that could directly affect cell communication, gene expression and host-pathogen interactions.

Supplementary Materials: The following are available online at http:/ /www.mdpi.com/2073-4425/9/8/400/s1, Supplementary Table S1: List of transcripts enriched in grasp $\Delta$ compared to the wild type strain (H99), Supplementary Table S2: List of transcripts enriched in atg7 compared to the wild type strain (H99), Supplementary Table S3: List of transcripts enriched in the EVs compared to the cell in the wild type strain H99, Supplementary Table S4: List of ncRNAs enriched in grasp $\Delta$ compared to the wild type strain (H99), Supplementary Table S5: List of ncRNAs enriched in atg7 $\Delta$ compared to the wild type strain (H99), Supplementary Figure S1: Electropherograms of the small-RNA content of EVs from the WT, grasp $\Delta$ and atg $7 \Delta$ strains of $C$. neoformans. The size in nucleotides (nt) and the fluorescence intensity (FU) are indicated on the corresponding axes of the graphs generated from the profiles shown on the left.

Author Contributions: R.P.d.S.: obtained the EVs, isolated the RNA, performed the analysis; S.d.T.M.: isolated the EVs, performed NTA analysis and the qPCR validation; J.R.: isolated the EVs and interpreted NTA results; F.C.G.d.R. isolated the EVs and interpreted NTA results; L.S.J. performed the EVs characterization; M.V. produced the mutant strains; L.K. obtained the EVs; D.L.O. obtained the EVs; R.P. analyzed the data, discussed the results, 
wrote the manuscript; S.G. discussed the results, wrote the manuscript; M.L.R. analyzed the data, wrote the manuscript; L.R.A. performed the RNA-seq, analyzed the data, wrote the manuscript. All authors discussed the results, wrote and approved the final manuscript.

Funding: This research received no external funding.

Acknowledgments: Rosana Puccia was supported by grants from the Brazilian agencies FAPESP, CNPq and CAPES. Marcio Lourenço Rodrigues was supported by grants from the Brazilian agencies FAPERJ and $\mathrm{CNPq}$ and by the Instituto Nacional de Ciência e Tecnologia de Inovação em Populações de Doenças Negligenciadas (INCT-IDPN). Samuel Goldenberg was supported by grants from the Brazilian agencies Fundação Araucária-PRONEX and CNPq.

Conflicts of Interest: The authors declare no conflict of interest.

\section{References}

1. Coakley, G.; Maizels, R.M.; Buck, A.H. Exosomes and other extracellular vesicles: The new communicators in parasite infections. Trends Parasitol. 2015, 31, 477-489. [CrossRef] [PubMed]

2. Tkach, M.; Théry, C. Communication by extracellular vesicles: Where we are and where we need to go. Cell 2016, 164, 1226-1232. [CrossRef] [PubMed]

3. Deatheragea, B.L.; Cooksona, B.T. Membrane vesicle release in bacteria, eukaryotes Eukaryotes and Archaea: A conserved yet underappreciated aspect of microbial life. Infect. Immun. 2012, 80, 1948-1957. [CrossRef] [PubMed]

4. Rodrigues, M.L.; Nimrichter, L.; Oliveira, D.L.; Frases, S.; Miranda, K.; Zaragoza, O.; Alvarez, M.; Nakouzi, A.; Feldmesser, M.; Casadevall, A. Vesicular polysaccharide export in Cryptococcus neoformans is a eukaryotic solution to the problem of fungal trans-cell wall transport. Eukaryot. Cell 2007, 6, 48-59. [CrossRef] [PubMed]

5. Albuquerque, P.C.; Nakayasu, E.S.; Rodrigues, M.L.; Frases, S.; Casadevall, A.; Zancope-Oliveira, R.M.; Almeida, I.C.; Nosanchuk, J.D. Vesicular transport in Histoplasma capsulatum: An effective mechanism for trans-cell wall transfer of proteins and lipids in ascomycetes. Cell Microbiol. 2008, 10, 1695-1710. [CrossRef] [PubMed]

6. Rodrigues, M.L.; Nakayasu, E.S.; Oliveira, D.L.; Nimrichter, L.; Nosanchuk, J.D.; Almeida, I.C.; Casadevall, A. Extracellular vesicles produced by Cryptococcus neoformans contain protein components associated with virulence. Eukaryot. Cell 2008, 7, 58-67. [CrossRef] [PubMed]

7. Eisenman, H.C.; Frases, S.; Nicola, A.M.; Rodrigues, M.L.; Casadevall, A. Vesicle-associated melanization in Cryptococcus neoformans. Microbiology 2009, 155, 3860-3867. [CrossRef] [PubMed]

8. Rizzo, J.; Oliveira, D.L.; Joffe, L.S.; Hu, G.; Gazos-Lopes, F.; Fonseca, F.L.; Almeida, I.C.; Frases, S.; Kronstad, J.W.; Rodrigues, M.L. Role of the Apt1 protein in polysaccharide secretion by Cryptococcus neoformans. Eukaryot. Cell 2014, 13, 715-726. [CrossRef] [PubMed]

9. Peres da Silva, R.; Puccia, R.; Rodrigues, M.L.; Oliveira, D.L.; Joffe, L.S.; César, G.V.; Nimrichter, L.; Goldenberg, S.; Alves, L.R. Extracellular vesicle-mediated export of fungal RNA. Sci. Rep. 2015, 5, 7763. [CrossRef] [PubMed]

10. Oliveira, D.L.; Nakayasu, E.S.; Joffe, L.S.; Guimarães, A.J.; Sobreira, T.J.; Nosanchuk, J.D.; Cordero, R.J.; Frases, S.; Casadevall, A.; Almeida, I.C.; et al. Biogenesis of extracellular vesicles in yeast: Many questions with few answers. Commun. Integr. Biol. 2010, 3, 533-535. [CrossRef] [PubMed]

11. Rodrigues, M.L.; Franzen, A.J.; Nimrichter, L.; Miranda, K. Vesicular mechanisms of traffic of fungal molecules to the extracellular space. Curr. Opin. Microbiol. 2013, 16, 414-420. [CrossRef] [PubMed]

12. Barr, F.A.; Puype, M.; Vandekerckhove, J.; Warren, G. GRASP65, a protein involved in the stacking of Golgi cisternae. Cell 1997, 91, 253-262. [CrossRef]

13. Shorter, J.; Watson, R.; Giannakou, M.E.; Clarke, M.; Warren, G.; Barr, F.A. GRASP55, a second mammalian GRASP protein involved in the stacking of Golgi cisternae in a cell-free system. EMBO J. 1999, 18, 4949-4960. [CrossRef] [PubMed]

14. Rabouille, C.; Malhotra, V.; Nickel, W. Diversity in unconventional protein secretion. J. Cell Sci. 2012, 125, 5251-5255. [CrossRef] [PubMed]

15. Gee, H.Y.; Noh, S.H.; Tang, B.L.; Kim, K.H.; Lee, M.G. Rescue of $\triangle F 508-C F T R$ trafficking via a GRASP-dependent unconventional secretion pathway. Cell 2011, 146, 746-760. [CrossRef] [PubMed]

16. Grieve, A.G.; Rabouille, C. Extracellular cleavage of E-cadherin promotes epithelial cell extrusion. J. Cell Sci. 2014, 127, 3331-3346. [CrossRef] [PubMed] 
17. Kinseth, M.A.; Anjard, C.; Fuller, D.; Guizzunti, G.; Loomis, W.F.; Malhotra, V. The Golgi-associated protein GRASP is required for unconventional protein secretion during development. Cell 2007, 130, 524-534. [CrossRef] [PubMed]

18. Duran, J.M.; Anjard, C.; Stefan, C.; Loomis, W.F.; Malhotra, V. Unconventional secretion of Acb1 is mediated by autophagosomes. J. Cell Biol. 2010, 188, 527-536. [CrossRef] [PubMed]

19. Manjithaya, R.; Anjard, C.; Loomis, W.F.; Subramani, S. Unconventional secretion of Pichia pastoris Acb1 is dependent on GRASP protein, peroxisomal functions and autophagosome formation. J. Cell Biol. 2010, 188, 537-546. [CrossRef] [PubMed]

20. Kmetzsch, L.; Joffe, L.S.; Staats, C.C.; de Oliveira, D.L.; Fonseca, F.L.; Cordero, R.J.; Casadevall, A.; Nimrichter, L.; Schrank, A.; Vainstein, M.H.; et al. Role for Golgi reassembly and stacking protein (GRASP) in polysaccharide secretion and fungal virulence. Mol. Microbiol. 2011, 81, 206-218. [CrossRef] [PubMed]

21. Glick, D.; Barth, S.; Macleod, K.F. Autophagy: Cellular and molecular mechanisms. J. Pathol. 2010, 221 , 3-12. [CrossRef] [PubMed]

22. Nakatogawa, H.; Suzuki, K.; Kamada, Y.; Ohsumi, Y. Dynamics and diversity in autophagy mechanisms: Lessons from yeast. Nat. Rev. Mol. Cell Biol. 2009, 10, 458-467. [CrossRef] [PubMed]

23. Lévêque, M.F.; Berry, L.; Cipriano, M.J.; Nguyen, H.M.; Striepen, B.; Besteiro, S. Autophagy-related protein ATG8 has a noncanonical function for apicoplast inheritance in Toxoplasma gondii. MBio 2015, 6, e01446-15. [CrossRef] [PubMed]

24. DeSelm, C.J.; Miller, B.C.; Zou, W.; Beatty, W.L.; van Meel, E.; Takahata, Y.; Klumperman, J.; Tooze, S.A.; Teitelbaum, S.L.; Virgin, H.W. Autophagy proteins regulate the secretory component of osteoclastic bone resorption. Dev. Cell 2011, 21, 966-974. [CrossRef] [PubMed]

25. Dreux, M.; Chisari, F.V. Impact of the autophagy machinery on hepatitis Hepatitis C virus infection. Viruses 2011, 3, 1342-1357. [CrossRef] [PubMed]

26. Zhang, Y.; Goldman, S.; Baerga, R.; Zhao, Y.; Komatsu, M.; Jin, S. Adipose-specific deletion of autophagy-related gene 7 (atg7) in mice reveals a role in adipogenesis. Proc. Natl. Acad. Sci. USA 2009, 106, 19860-19865. [CrossRef] [PubMed]

27. Lee, I.H.; Kawai, Y.; Fergusson, M.M.; Rovira, I.I.; Bishop, A.J.; Motoyama, N.; Cao, L.; Finkel, T. Atg7 modulates p53 activity to regulate cell cycle and survival during metabolic stress. Science 2012, 336, 225-228. [CrossRef] [PubMed]

28. Oliveira, D.L.; Fonseca, F.L.; Zamith-Miranda, D.; Nimrichter, L.; Rodrigues, J.; Pereira, M.D.; Reuwsaat, J.C.; Schrank, A.; Staats, C.; Kmetzsch, L.; et al. The putative autophagy regulator Atg7 affects the physiology and pathogenic mechanisms of Cryptococcus neoformans. Future Microbiol. 2016, 11, 1405-1419. [CrossRef] [PubMed]

29. Bruns, C.; McCaffery, J.M.; Curwin, A.J.; Duran, J.M.; Malhotra, V. Biogenesis of a novel compartment for autophagosome-mediated unconventional protein secretion. J. Cell Biol. 2011, 195, 979-992. [CrossRef] [PubMed]

30. Maas, S.L.N.; De Vrij, J.; Van Der Vlist, E.J.; Geragousian, B.; Van Bloois, L.; Mastrobattista, E.; Schiffelers, R.M.; Wauben, M.H.M.; Broekman, M.L.D.; Nolte-'t Hoen, E.N. Possibilities and limitations of current technologies for quantification of biological extracellular vesicles and synthetic mimics. J. Control. Release 2015, 200, 87-96. [CrossRef] [PubMed]

31. Pfaffl, M.W. A new mathematical model for relative quantification in real-time RT-PCR. Nucleic Acids Res. 2001, 29, e45. [CrossRef] [PubMed]

32. Rodrigues, M.L.; Oliveira, D.L.; Vargas, G.; Girard-Dias, W.; Franzen, A.J.; Frasés, S.; Miranda, K.; Nimrichter, L. Analysis of yeast extracellular vesicles. Methods Mol. Biol. 2016, 1459, 175-190. [CrossRef] [PubMed]

33. Baggerly, K.A.; Deng, L.; Morris, J.S.; Aldaz, C.M. Differential expression in SAGE: Accounting for normal between-library variation. Bioinformatics 2003, 19, 1477-1483. [CrossRef] [PubMed]

34. Semenza, J.C.; Hardwick, K.G.; Dean, N.; Pelham, H.R. ERD2, a yeast gene required for the receptor-mediated retrieval of luminal ER proteins from the secretory pathway. Cell 1990, 61, 1349-1357. [CrossRef]

35. Von Mollard, G.; Stevens, T.H. The Saccharomyces cerevisiae v-SNARE Vti1p is required for multiple membrane transport pathways to the vacuole. Mol. Biol. Cell 1999, 10, 1719-1732. [CrossRef] [PubMed]

36. Abels, E.R.; Breakefield, X.O. Introduction to extracellular vesicles: Biogenesis, RNA cargo selection, content, release and uptake. Cell. Mol. Neurobiol. 2016, 36, 301-312. [CrossRef] [PubMed] 
37. Li, C.; Lev, S.; Saiardi, A.; Desmarini, D.; Sorrell, T.C.; Djordjevic, J.T. Identification of a major IP5 kinase in Cryptococcus neoformans confirms that PP-IP5/IP7, not IP6, is essential for virulence. Sci. Rep. 2016, 6, 23927. [CrossRef] [PubMed]

38. Gonzalez-Hilarion, S.; Paulet, D.; Lee, K.T.; Hon, C.C.; Lechat, P.; Mogensen, E.; Moyrand, F.; Proux, C.; Barboux, R.; Bussotti, G.; et al. Intron retention-dependent gene regulation in Cryptococcus neoformans. Sci. Rep. 2016, 6, 32252. [CrossRef] [PubMed]

39. Keam, S.P.; Hutvagner, G. tRNA-Derived Fragments (tRFs): Emerging new roles for an ancient RNA in the regulation of gene expression. Life 2015, 5, 1638-1651. [CrossRef] [PubMed]

40. Maute, R.L.; Schneider, C.; Sumazin, P.; Holmes, A.; Califano, A.; Basso, K.; Dalla-Favera, R. tRNA-derived microRNA modulates proliferation and the DNA damage response and is down-regulated in $\mathrm{B}$ cell lymphoma. Proc. Natl. Acad. Sci. USA 2013, 110, 1404-1409. [CrossRef] [PubMed]

41. Gebetsberger, J.; Zywicki, M.; Künzi, A.; Polacek, N. tRNA-derived fragments target the ribosome and function as regulatory non-coding RNA in Haloferax volcanii. Archaea 2012, 2012, 260909. [CrossRef] [PubMed]

42. Lee, Y.S.; Shibata, Y.; Malhotra, A.; Dutta, A. A novel class of small RNAs: tRNA-derived RNA fragments (tRFs). Genes Dev. 2009, 23, 2639-2649. [CrossRef] [PubMed]

43. Haussecker, D.; Huang, Y.; Lau, A.; Parameswaran, P.; Fire, A.Z.; Kay, M.A. Human tRNA-derived small RNAs in the global regulation of RNA silencing. RNA 2010, 16, 673-695. [CrossRef] [PubMed]

44. Couvillion, M.T.; Bounova, G.; Purdom, E.; Speed, T.P.; Collins, K. A Tetrahymena Piwi bound to mature tRNA $3^{\prime}$ fragments activates the exonuclease Xrn2 for RNA processing in the nucleus. Mol. Cell 2012, 48, 509-520. [CrossRef] [PubMed]

45. Goodarzi, H.; Liu, X.; Nguyen, H.C.; Zhang, S.; Fish, L.; Tavazoie, S.F. Endogenous tRNA-derived fragments suppress breast cancer progression via YBX1 displacement. Cell 2015, 161, 790-802. [CrossRef] [PubMed]

46. Garcia-Silva, M.R.; Cabrera-Cabrera, F.; das Neves, R.F.; Souto-Padrón, T.; de Souza, W.; Cayota, A. Gene expression changes induced by Trypanosoma cruzi shed microvesicles in mammalian host cells: Relevance of tRNA-derived halves. BioMed Res. Int. 2014, 2014, 305239. [CrossRef] [PubMed]

47. Garcia-Silva, M.R.; das Neves, R.F.; Cabrera-Cabrera, F.; Sanguinetti, J.; Medeiros, L.C.; Robello, C.; Naya, H.; Fernandez-Calero, T.; Souto-Padron, T.; de Souza, W.; et al. Extracellular vesicles shed by Trypanosoma cruzi are linked to small RNA pathways, life cycle regulation and susceptibility to infection of mammalian cells. Parasitol. Res. 2014, 113, 285-304. [CrossRef] [PubMed]

48. Nolte-'t Hoen, E.N.; Buermans, H.P.; Waasdorp, M.; Stoorvogel, W.; Wauben, M.H.; 't Hoen, P.A. Deep sequencing of RNA from immune cell-derived vesicles uncovers the selective incorporation of small non-coding RNA biotypes with potential regulatory functions. Nucleic Acids Res. 2012, 40, 9272-9285. [CrossRef] [PubMed]

49. Vojtech, L.; Woo, S.; Hughes, S.; Levy, C.; Ballweber, L.; Sauteraud, R.P.; Strobl, J.; Westerberg, K.; Gottardo, R.; Tewari, M.; et al. Exosomes in human semen carry a distinctive repertoire of small non-coding RNAs with potential regulatory functions. Nucleic Acids Res. 2014, 42, 7290-7304. [CrossRef] [PubMed]

50. Huotari, J.; Helenius, A. Endosome maturation. EMBO J. 2011, 30, 3481-3500. [CrossRef] [PubMed]

51. Hanson, P.I.; Cashikar, A. Multivesicular body morphogenesis. Annu. Rev. Cell Dev. Biol. 2012, 28, 337-362. [CrossRef] [PubMed]

52. Oliveira, D.L.; Rizzo, J.; Joffe, L.S.; Godinho, R.M.; Rodrigues, M.L. Where do they come from and where do they go: Candidates for regulating extracellular vesicle formation in fungi. Int. J. Mol. Sci. 2013, 14, 9581-9603. [CrossRef] [PubMed]

53. Malhotra, V. Unconventional protein secretion: An evolving mechanism. EMBO J. 2013, 32, 1660-1664. [CrossRef] [PubMed]

(C) 2018 by the authors. Licensee MDPI, Basel, Switzerland. This article is an open access article distributed under the terms and conditions of the Creative Commons Attribution (CC BY) license (http://creativecommons.org/licenses/by/4.0/). 